\title{
Analysis on the Formation of $\mathrm{Li}_{4} \mathrm{SiO}_{4}$ and $\mathrm{Li}_{2} \mathrm{SiO}_{3}$ through First Principle Calculations and Comparing with Experimental Data Related to Lithium Battery
}

\author{
Chil-Hoon Doh ${ }^{\mathrm{a}, \uparrow}$, Angathevar Veluchamy ${ }^{\mathrm{b}}$, Min-Wook $\mathrm{Oh}^{\mathrm{c}}$, and Byung-Chan Han ${ }^{\mathrm{c}}$ \\ ${ }^{a}$ Korea Electrotechnology Research Institute, Changwon 641-600,Korea \\ ${ }^{b}$ Central Electrochemical Research Institute, Karaikudi 630006, India \\ ${ }^{c}$ Department of Energy Systems Engineering, DGIST, Daegu 711-873, Korea
}

\begin{abstract}
The formation of $\mathrm{Li}-\mathrm{Si}-\mathrm{O}$ phases, $\mathrm{Li}_{4} \mathrm{SiO}_{4}$ and $\mathrm{Li}_{2} \mathrm{SiO}_{3}$ from the starting materials $\mathrm{SiO}$ and $\mathrm{Li}_{2} \mathrm{Oare}$ analyzed using Vienna Ab-initio Simulation (VASP) package and the total energies of Li-Si-O compounds are evaluated using Projector Augmented Wave (PAW) method and correlated the structural characteristics of the binary system $\mathrm{SiO}-\mathrm{Li}_{2} \mathrm{O}$ with experimental data from electrochemical method. Despite $\mathrm{Li}_{2} \mathrm{SiO}_{3}$ becomes stable phase by virtue of lowest formation energy calculated through VASP, the experimental method shows presence of $\mathrm{Li}_{4} \mathrm{SiO}_{4}$ as the only product formed when $\mathrm{SiO}$ and $\mathrm{Li}_{2} \mathrm{O}$ reacts during slow heating to reach $550^{\circ} \mathrm{C}$ and found no evidence for the formation of $\mathrm{Li}_{2} \mathrm{SiO}_{3}$. Also, higher density of $\mathrm{Li}_{4} \mathrm{SiO}_{4}\left(2.42 \mathrm{~g} \mathrm{ml}^{-1}\right)$ compared to the compositional mixture $1 \mathrm{SiO}_{2}-$ $2 \mathrm{Li}_{2} \mathrm{O}\left(2.226 \mathrm{~g} \mathrm{ml}^{-1}\right)$ and better cycle capacity observed through experiment proves that $\mathrm{Li}_{4} \mathrm{SiO}_{4}$ as the most stable anode supported by better cycleabilityfor lithium ion battery remains as paradox from the point of view of VASP calculations.
\end{abstract}

Keywords : Silicon monoxide, Graphite, $\mathrm{Li}_{4} \mathrm{SiO}_{4}, \mathrm{Li}_{2} \mathrm{SiO}_{3}$, $\mathrm{Li}-\mathrm{Si}-\mathrm{O}$, VASP

Received July 28, 2011 : Accepted September 24, 2011

\section{Introduction}

The search for high specific capacity anode alternative to the low capacity graphite $(372 \mathrm{mAh} / \mathrm{g})$ of lithium ion battery has opened up new area of research based on tin and silicon which have specific capacity values of 4190 and $990 \mathrm{mAh} / \mathrm{g}$ corresponding to $\mathrm{Li}_{22} \mathrm{Si}_{5}$ and $\mathrm{Li}_{22} \mathrm{Sn}_{5}$ alloys respectively. ${ }^{1-2)}$ Despite exhibiting high initial capacities, the crystallographic volume changes of these electrodes during cycling cause premature cell failure. In the case of silicon based composite a reasonable level of cycle capacity has been achieved employing dual composites comprising of $\mathrm{Si}$ or $\mathrm{SiO}$ with graphite. Improvements in performance have been reported by incorporating

${ }^{\dagger}$ Corresponding author. Tel.: +82-55-280-1662

E-mail address: chdoh@keri.re.kr metal powders, ${ }^{3)}$ silicon alloys, ${ }^{4)}$ silicon compounds ${ }^{5)}$ and carbon coatings to the composites. ${ }^{6-7)}$ The silicon oxide based composite anodes perform better over silicon based ones as the former generates a buffer component $\mathrm{Li}_{2} \mathrm{O}$ along with possibly nanoslicon during the first cycling which reduces electrode strain during cycling process. ${ }^{8)}$ Later, Miyachi et al. ${ }^{9}$ explained that high performance of $\mathrm{SiO}$ based composite is due to silicate formation in the electrode which acts both as volume buffer and electroactive species. Even though different mechanisms are reported to explain the high cycleability of $\mathrm{SiO}$, a report by Schulmeister and Mader ${ }^{10)}$ states that the commercially produced $\mathrm{SiO}$ is not a single phase compound but a mixture of amorphous $\mathrm{SiO}_{2}$ and amorphous $\mathrm{Si}$. Such findings could explain the complicated chemistry of $\mathrm{SiO}$ based anode comprising duringcharge/discharge process. Further improvement in electrode performance was made by 
incorporating/generating inert material such as $\mathrm{Li}_{2} \mathrm{O},{ }^{11,12)}$ $\mathrm{Al}_{2} \mathrm{O}_{3},{ }^{13)} \mathrm{SiO}_{2}{ }^{14)}$ during synthesis and first lithiation process. Interdependency of sustainable reversible capacity and initial irreversible capacity $\left(\mathrm{Li}_{2} \mathrm{O}\right)$ of the electrode materials has also been reported for the $\mathrm{SiO} / \mathrm{C}$ composite. ${ }^{15)}$ The composite material consisting of nano-sized silicon, $\mathrm{Li}_{4} \mathrm{SiO}_{4}{ }^{16)}$ and $\mathrm{Li}$-doped $\mathrm{SiO}$-negative material $(\mathrm{LixSiO})^{17}$ are capable of delivering high capacity with a flat plateau in the cycle life performance.

$\mathrm{SiO}$ is generally prepared by rapid condensation of vapor (gaseous $\mathrm{SiO}$ ) formed when pure $\mathrm{Si}$ and pure quartz $\left(\mathrm{SiO}_{2}\right)$ are reacted in a vacuum at high temperatures ${ }^{18)}$ or reduction of $\mathrm{SiO}_{2}$ with $\mathrm{H}_{2}$ or $\mathrm{CO}$ at high temperatures ${ }^{19)}$ as shown by the reactions (1) and (2) respectively. Silicon monoxide could be trapped in an argon matrix cooled by helium ${ }^{20)}$ which eventually decomposes into $\mathrm{SiO}_{2}$ and $\mathrm{Si}^{21}{ }^{21}$

$$
\begin{aligned}
& \mathrm{SiO}_{2}+\mathrm{Si} \rightarrow 2 \mathrm{SiO} \\
& \left.\mathrm{SiO}_{2}+\mathrm{H}_{2} \text { (or } \mathrm{CO}\right) \rightarrow 2 \mathrm{SiO}+\mathrm{H}_{2} \mathrm{O}\left(\text { or } \mathrm{CO}_{2}\right)
\end{aligned}
$$

This paper compares the electrochemical and structural data obtained for the experimentally synthesized compound from the starting materials $\mathrm{SiO}$ and $\mathrm{Li}_{2} \mathrm{O}$ with the possible compound that could be expected from the first principle calculations using VASP. The paradox that underlies in formation of the product is analyzed by considering the data such as formation energies, density values and electrochemical data.

\section{Methodology}

\subsection{Experimental}

Equimolecular quantities of lithium hydroxide monohydrate $\left(\mathrm{LiOH} \cdot \mathrm{H}_{2} \mathrm{O}\right.$, Aldrich) and $\mathrm{SiO}(\sim 325$ mesh, LTS Chemicals Inc.) were mixed in a mortar and then heated to $550^{\circ} \mathrm{C}$ for $3 \mathrm{~h}$ in an argon atmosphere. Graphite was then added to maintain the weight ratio of $\mathrm{C}$ and $\mathrm{SiO}$ at $1: 1$ and ball-milled for $15 \mathrm{~h}$. The composite was named as ' $A$ '. In order to understand the behavior of the new composite ' $A$ ' another composite ' $B$ ' was prepared by just ball milling $\mathrm{SiO}$ and graphite in a weight ratio of $1: 1$ for $15 \mathrm{~h}$.

The composite powders 'A' and 'B' were then examined by means of a Philips 1830 X-ray diffractometer with nickel-filtered $\mathrm{Cu}$ Ká radiation at a scan rate of $0.04^{\circ} \mathrm{s}^{-1}$ over a $2 \theta$ range of $10 \sim 80^{\circ}$. The composite 'A' material was used to prepare a composite electrode named as (A) and its electrochemical properties were compared with electrode (B) prepared by using the composite
' $\mathrm{B}$ '. Conditions of the electrode and cell preparation were described elsewhere. ${ }^{22-23)}$ The coin cell of anodes of (A) and (B) with lithium counter electrode were cycled between 0 and $1.5 \mathrm{~V}$ versus $\mathrm{Li}^{+} / \mathrm{Li}^{0}$ at a constant currentof $0.253 \mathrm{mAcm}^{-2}(1 / 10 \mathrm{C}$ rate based on the theoretical capacity of graphite) using a charge-discharge analyzer (Toyo System Co., Ltd. Japan).

\subsection{Computational}

The crystallographic data of Li-Si-O phases are obtained from inorganic materials database and published papers. The total-energy calculation and full structural optimization of Li-Si-O compounds were performed using the Vienna ab initio Simulation Package (VASP). ${ }^{24-25)}$ Projector augmented-wave pseudopotentials were used. ${ }^{26)}$ The exchange and correlation were treated within the generalized gradient approximation (GGA-PBE) ${ }^{27)}$ The size of the k-mesh was chosen appropriately as shown in Table 2 through KPOINTS convergence test. The result of KPOINTS convergence was shown in Fig. 4. The value of $\mathrm{x}$-axis means the multiplicity of KPOINTS as shown in Table 2 . When the multiplicity of KPOINTS was changed in the range of 1/2,1,2 and 3, the formation energy differences of different multiplicity of 1,2 and 3 were lower than $1 \mathrm{meV} / \mathrm{unit}$ reactant except that of $1 / 2$. In INCAR, ISMEAR of 1, EDIFF(electronic accuracy) of $1 \times 10^{-5} \mathrm{eV}$, EDIFFG(ionic accuracy) of $-0.02 \mathrm{eV}$ were used. A cutoff value of $400 \mathrm{eV}$ was used to assure convergence of the energy. It was found that the convergence in the total energy was better than $1 \mathrm{meV} /$ atom using this cutoff energy and k-mesh grid. Total-energy minimization via a lattice parameter optimization and atomic position relaxation in a conjugate gradient routine was obtained by calculating the Hellmann-Feynman forces which are reduced to within the $0.01 \mathrm{eV} / \AA$ for each atom. Other computational and structural details are available in references. ${ }^{28)}$

\section{Results and discussion}

\subsection{Reaction and theoretical specific capacity}

The formation of $\mathrm{L}_{4} \mathrm{SiO}_{4}$ phase by the reaction of $\mathrm{SiO}$ and $\mathrm{Li}_{2} \mathrm{O}$ around $550^{\circ} \mathrm{C}$ has been reported earlier ${ }^{29)}$ as shown in Fig. 1. The stable compositions of Li-Si-O ternary material are described in Fig. 2. Li-Si-O ternary materials could be treated as pueudobinary materials of $\mathrm{Li}_{2} \mathrm{O}$ and $\mathrm{SiO}_{2}$.

The structure of $\mathrm{SiO}$ is reported to follow interface clusters mixture model (ICM model) ${ }^{30)}$ composed of 


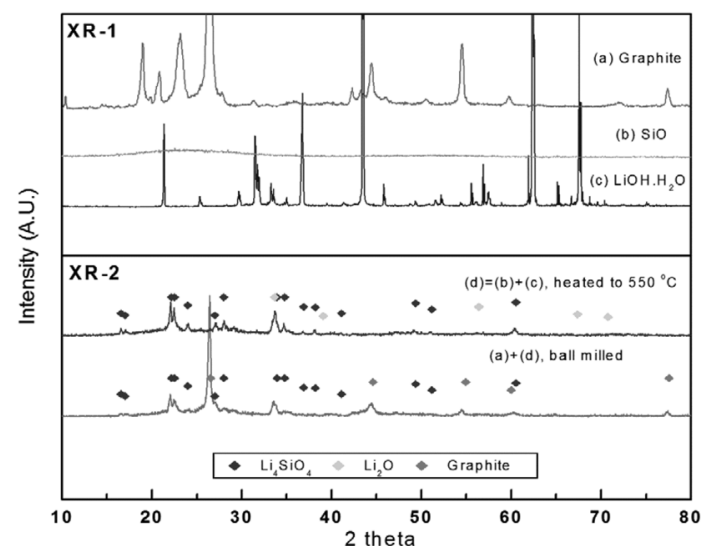

Fig. 1. XR-1 represents XRD pattern of (a) graphite (b) $\mathrm{SiO}$, (c) $\mathrm{LiOH} \cdot \mathrm{H}_{2} \mathrm{O}, \mathrm{XR}-2$ represents $\mathrm{d}=(\mathrm{b})+(\mathrm{c})$ material heated at $550^{\circ} \mathrm{C}$ in argon atmosphere and (a) $+(\mathrm{d})$ ball milled composite material.

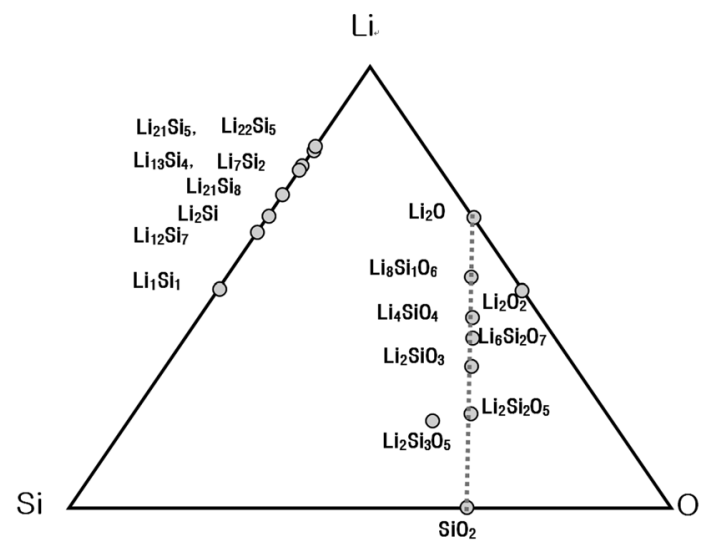

Fig. 2. A phase diagram of $\mathrm{Li}-\mathrm{Si}-\mathrm{O}$ ternary and $\mathrm{Li}_{2} \mathrm{O}-\mathrm{SiO}_{2}$ pseudobinary materials.

nanometric domains of $\mathrm{Si}$ and $\mathrm{SiO}_{2}$. Following ICM model, chemical reaction of $\mathrm{SiO}$ and $\mathrm{Li}_{2} \mathrm{O}$ is expected to produce products based on Li-Si-O arrangements. Confining Li-Si-O compounds as $\mathrm{Li}_{4} \mathrm{SiO}_{4}$ the chemical reaction is represented as follows,

$$
\begin{aligned}
& 2 \mathrm{SiO} \rightarrow \mathrm{Si}+\mathrm{SiO}_{2} \\
& \mathrm{SiO}_{2}+2 \mathrm{Li}_{2} \mathrm{O} \rightarrow \mathrm{Li}_{4} \mathrm{SiO}_{4} \\
& 2 \mathrm{SiO}+2 \mathrm{Li}_{2} \mathrm{O} \rightarrow 2 \mathrm{Li}_{4} \mathrm{SiO}_{4}+\mathrm{Si}
\end{aligned}
$$

Reaction (3) is a disproportionation reaction, changed the oxidation state of silicon in $\mathrm{SiO}$ from +2 to 0 in the case of nano $\mathrm{Si}$ and +4 oxidation state in $\mathrm{SiO}_{2}$ and $\mathrm{Li}_{4} \mathrm{SiO}_{4}$. Silicon compounds having +4 oxidation stateisinert to electrochemical reaction with lithium. Reaction (3) shows that a half of $\mathrm{SiO}$ gets converted into $\mathrm{Li}_{4} \mathrm{SiO}_{4}$, which possibly remains as an electrochemically inactive species $\left(\Delta \mathrm{G}^{\mathrm{o}}{ }_{298 \mathrm{~K}}=-2366 \mathrm{~kJ} / \mathrm{mole}\right)^{31)}$ in the composite similar to that reported by Yang et al. ${ }^{32)}$ The fully lithiated silicon was known as $\mathrm{Li}_{22} \mathrm{Si}_{5}$ (Eq. 4). However, $\mathrm{Li}_{15} \mathrm{Si}_{4}$ phase was known as a fully lithiated silicon compound under electrochemical condition at room temperature. ${ }^{33-34)}$

$$
22 \mathrm{Li}+5 \mathrm{Si} \rightarrow 2 \mathrm{Li}_{22} \mathrm{Si}_{5}
$$

By combining the reactions (3) and (4), the theoretical specific capacity of $\mathrm{SiO}$ and $\left(\mathrm{Si}-\mathrm{Li}_{4} \mathrm{SiO}_{4}\right)$ will be $1337 \mathrm{mAh} / \mathrm{g}-\mathrm{SiO}$ (Eq. 5) and $797 \mathrm{mAh} / \mathrm{g}-\left(\mathrm{Si}_{-} \mathrm{Li}_{4} \mathrm{SiO}_{4}\right)$ (Eq. 6), respectively. Formula ratio of $\mathrm{SiO}$ and $\mathrm{Li}_{2} \mathrm{O}$ materials used in this experiment was 4 and 2 leading to theoretical specific capacity of $999 \mathrm{mAh} / \mathrm{g}-(2 \mathrm{Si}-$ $\mathrm{SiO}_{2}-\mathrm{Li}_{4} \mathrm{SiO}_{4}$ ) (Eq. 7).

$26800 \mathrm{mAh} /$ eq.-Li $\times(22 / 5)$ eq.-Li/eq.-Six (1/2)eq.$\mathrm{Si}$ /eq. $\mathrm{SiO} \times(1 / 44.0849)$ eq. $/ \mathrm{g}-\mathrm{SiO}=1337 \mathrm{mAh} / \mathrm{g}-$ $\mathrm{SiO}$

$26800 \mathrm{mAh} /$ eq.-Li $\times(22 / 5)$ eq.-Li/eq.-Si $\times$ 1eq.-Si/ eq. $-\left(\mathrm{Si}_{-}-\mathrm{Li}_{4} \mathrm{SiO}_{4}\right) \times(1 / 147.9326)$ eq. $/ \mathrm{g}-\left(\mathrm{Si}-\mathrm{Li}_{4} \mathrm{SiO}_{4}\right)=$ $797 \mathrm{mAh} / \mathrm{g}-\left(\mathrm{Si}_{-} \mathrm{Li}_{4} \mathrm{SiO}_{4}\right)$

$26800 \mathrm{mAh} /$ eq.-Li $\times(22 / 5)$ eq.-Li/eq.-Si $\times 2$ eq. $-\mathrm{Si} /$ eq. $-\left(2 \mathrm{Si}_{-} \mathrm{SiO}_{2}-\mathrm{Li}_{4} \mathrm{SiO}_{4}\right) \times(1 / 236.1024)$ eq. $/ \mathrm{g}-\left(2 \mathrm{Si}-\mathrm{SiO}_{2}-\right.$ $\left.\mathrm{Li}_{4} \mathrm{SiO}_{4}\right)=999 \mathrm{mAh} / \mathrm{g}-\left(2 \mathrm{Si}_{-} \mathrm{SiO}_{2}-\mathrm{Li}_{4} \mathrm{SiO}_{4}\right)$

\subsection{Specific capacity and cycle behavior}

Variation of specific capacity with cycle number for the heat treated- $\left(\mathrm{SiO}+\mathrm{Li}_{2} \mathrm{O}\right) / \mathrm{C}$ electrode $(\mathrm{A})$ and $\mathrm{SiO} / \mathrm{C}$ electrode (B) are shown as Fig. $3{ }^{35)}$ The first lithiation specific capacity of electrode (A) is $862 \mathrm{mAh} / \mathrm{g}$ which gets reduced to $521 \mathrm{mAh} / \mathrm{g}$ in the second cycle and simi-

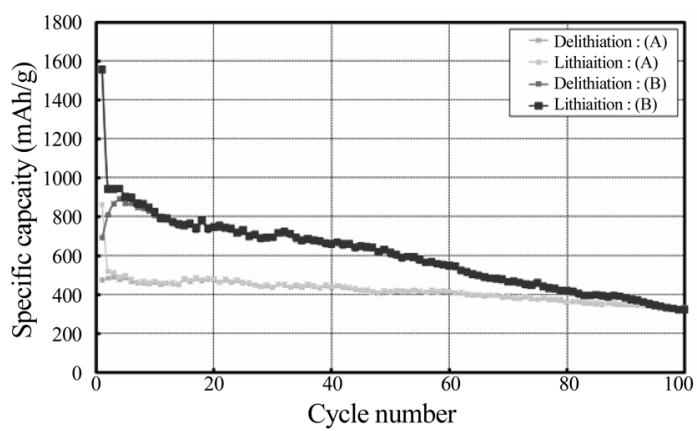

Fig. 3. Cycle life curves of electrode $(\mathrm{A})$ : heat treated-( $\mathrm{SiO}+$ $\mathrm{LiOH} . \mathrm{H}_{2} \mathrm{O}$ )/Graphite and electrode (B) : $\mathrm{SiO} /$ Graphite. Potential range $0 \sim 1.5 \mathrm{~V}$ vs. $\mathrm{Li} / \mathrm{Li}^{+}$, current density $0.253 \mathrm{mAh} / \mathrm{cm}^{2}$. 


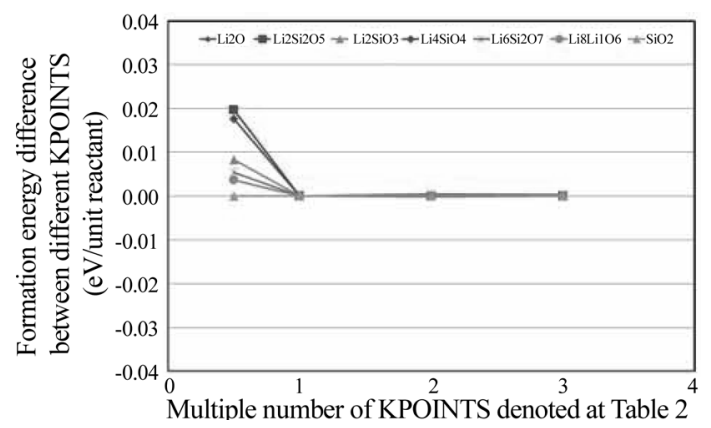

Fig. 4. KPOINTS convergence results.

larly for the electrode $\mathrm{SiO} / \mathrm{C}(\mathrm{B})$ the value $1556 \mathrm{mAh} / \mathrm{g}$ is reduced to $950 \mathrm{mAh} / \mathrm{g}$. Theoretical specific capacity of $\left(2 \mathrm{Si}_{-} \mathrm{SiO}_{2}-\mathrm{Li}_{4} \mathrm{SiO}_{4}\right) / \mathrm{C}(1: 1)$ electrode $(\mathrm{A})$ and $\mathrm{SiO} /$ $\mathrm{C}(1: 1)$ electrode (B) will be $685.5 \mathrm{mAh} / \mathrm{g}-\left(2 \mathrm{Si}_{-} \mathrm{SiO}_{2}\right.$ $\mathrm{Li}_{4} \mathrm{SiO}_{4} / \mathrm{C}(1: 1)$, Eq. 8$)$ and $854.5 \mathrm{mAh} / \mathrm{g}-(\mathrm{SiO} / \mathrm{C}(1: 1)$, Eq. 9), respectively.Capacity retentions of $\left(2 \mathrm{Si}^{-\mathrm{SiO}_{2}-}\right.$ $\left.\mathrm{Li}_{4} \mathrm{SiO}_{4}\right) / \mathrm{C}(1: 1)$ electrode (A) and $\mathrm{SiO} / \mathrm{C}(1: 1)$ electrode (B) were $67 \%$ and $36 \%$ at $100^{\text {th }}$ cycle against the maximum capacity, respectively, showing better cycle performance for $\mathrm{Li}_{4} \mathrm{SiO}_{4}$ based electrode.

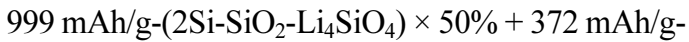
$\mathrm{C} \times 50 \%=685.5 \mathrm{mAh} / \mathrm{g}-\left(2 \mathrm{Si}_{-} \mathrm{SiO}_{2}-\mathrm{Li}_{4} \mathrm{SiO}_{4}\right) / \mathrm{C}(1: 1)$
$1337 \mathrm{mAh} / \mathrm{g}-\mathrm{SiO} \times 50 \%+372 \mathrm{mAh} / \mathrm{g}-\mathrm{C} \times 50 \%=$ $854.5 \mathrm{mAh} / \mathrm{g}-\mathrm{SiO} / \mathrm{C}(1: 1)$

\subsection{Structural properties and densities of Li-Si-O} phases

Possibilities of the formation of $\mathrm{Li}_{4} \mathrm{SiO}_{4}$ could beunderstood from the first principle calculations. Phase diagram for Li-Si-O ternary materials has been drawn with the aid of datafrom JCPDSis represented as Fig. 2. Stable phases of Li-Si binary system denote the favorable electrochemical reactions of $\mathrm{Li}$ with $\mathrm{Si}$ host material.Stable Li-Si-O ternary phases could be encountered as pseudo-binary materials of $\mathrm{Li}_{2} \mathrm{O}$ and $\mathrm{SiO}_{2}$.Structural information of stable Li-Si-O phases is summarized in Table 1.

Total energiesof stable Li-Si-O ternary materials evaluatedby VASP (Vienna Ab-initio Simulation Package)are shown in the Table 2.

Stable Li-Si-O phases can be formed by reaction of $\mathrm{Li}_{2} \mathrm{O}$ and $\mathrm{SiO}_{2}$ as shown in reaction (10)

$$
x \mathrm{Li}_{2} \mathrm{O}+\mathrm{ySiO}_{2} \rightarrow \mathrm{Li}_{2 \mathrm{x}} \mathrm{Si}_{\mathrm{y}} \mathrm{O}_{\mathrm{x}+2 \mathrm{y}}
$$

Formation energy $=\mathrm{E}_{0}\left(\mathrm{Li}_{2 \mathrm{x}} \mathrm{Si}_{\mathrm{y}} \mathrm{O}_{\mathrm{x}+2 \mathrm{y}}\right)-\left(x \mathrm{E}_{0}\left(\mathrm{Li}_{2} \mathrm{O}\right)+\right.$ $\left.\mathrm{yE}_{0}\left(\mathrm{SiO}_{2}\right)\right)$

$(\Delta \mathrm{H}, \mathrm{eV} / \mathrm{unit}(\mathrm{x}+\mathrm{y}))$

In Fig. 5 the formation energies of the stable Li-Si-O

Table 1. The structural information of the stable Li-Si-O phases

\begin{tabular}{|c|c|c|c|c|c|c|c|c|c|c|c|}
\hline \multirow{2}{*}{ Material } & \multirow{2}{*}{ Space group } & \multirow{2}{*}{ ICSD no. } & \multirow{2}{*}{$\begin{array}{l}\text { Mole content } \\
\text { of } \mathrm{Li}_{2} \mathrm{O}(\%)\end{array}$} & & \multicolumn{6}{|c|}{ Lattice parameters } & \multirow{2}{*}{$\begin{array}{c}\text { Density } \\
(\mathrm{g} / \mathrm{ml})\end{array}$} \\
\hline & & & & & $\mathrm{a}(\AA)$ & $\mathrm{b}(\AA)$ & $c(\AA)$ & $\alpha\left({ }^{\circ}\right)$ & $\beta\left({ }^{\circ}\right)$ & $\gamma\left(\left(^{\circ}\right)\right.$ & \\
\hline \multirow[t]{2}{*}{$\mathrm{Li}_{2} \mathrm{O}$} & \multirow[t]{2}{*}{ Fm3-m } & \multirow[t]{2}{*}{60431} & \multirow[t]{2}{*}{100} & ICSD & 4.619 & 4.619 & 4.619 & 90 & 90 & 90 & \multirow[t]{2}{*}{2.014} \\
\hline & & & & Calculated & 4.619 & 4.619 & 4.619 & 90 & 90 & 90 & \\
\hline \multirow{2}{*}{$\mathrm{Li}_{2} \mathrm{Si}_{2} \mathrm{O}_{5}$} & \multirow[t]{2}{*}{ CCG2 } & \multirow[t]{2}{*}{52157} & \multirow[t]{2}{*}{$100 / 3$} & ICSD & 5.778 & 7.840 & 4.755 & 90 & 90 & 68.4 & \multirow[t]{2}{*}{2.466} \\
\hline & & & & calculated & 5.767 & 7.842 & 4.748 & 90 & 90 & 68.4 & \\
\hline \multirow[t]{2}{*}{$\mathrm{Li}_{2} \mathrm{SiO}_{3}$} & \multirow[t]{2}{*}{ Cmc21 } & \multirow[t]{2}{*}{853} & \multirow[t]{2}{*}{50} & ICSD & 9.325 & 5.374 & 4.644 & 90 & 90 & 29.8 & \multirow[t]{2}{*}{2.529} \\
\hline & & & & calculated & 9.311 & 5.365 & 4.638 & 90 & 90 & 29.8 & \\
\hline \multirow{2}{*}{$\mathrm{Li}_{4} \mathrm{SiO}_{4}$} & \multirow[t]{2}{*}{$\mathrm{P} 21 / \mathrm{m}$} & \multirow[t]{2}{*}{8222} & \multirow[t]{2}{*}{$200 / 3$} & ICSD & 11.405 & 6.040 & 16.680 & 90 & 99 & 90 & \multirow[t]{2}{*}{2.420} \\
\hline & & & & calculated & 11.405 & 6.040 & 16.600 & 90 & 99.4 & 90 & \\
\hline \multirow{2}{*}{$\mathrm{Li}_{6} \mathrm{Si}_{2} \mathrm{O}_{7}$} & \multirow{2}{*}{ P4-21m } & \multirow{2}{*}{25752} & \multirow{2}{*}{60} & ICSD & 7.671 & 7.671 & 4.798 & 90 & 90 & 90 & \multirow{2}{*}{2.413} \\
\hline & & & & calculated & 7.671 & 7.671 & 4.798 & 90 & 90 & 90 & \\
\hline \multirow[t]{2}{*}{$\mathrm{Li}_{8} \mathrm{Si}_{1} \mathrm{O}_{6}$} & \multirow[t]{2}{*}{$\mathrm{P} 63 \mathrm{~cm}$} & \multirow[t]{2}{*}{65176} & \multirow[t]{2}{*}{80} & ICSD & 5.379 & 5.379 & 10.561 & 90 & 90 & 120 & 2.203 \\
\hline & & & & calculated & 5.369 & 5.369 & 10.544 & 90 & 90 & 120 & \\
\hline $\mathrm{SiO}_{2}$-á & $\mathrm{P} 3_{1} 21$ & 67117 & 0 & ICSD & 4.831 & 4.831 & 5.353 & 90 & 90 & 120 & 2.650 \\
\hline & & & & calculated & 4.830 & 4.830 & 5.353 & 90 & 90 & 120 & \\
\hline
\end{tabular}


Table 2. The total energies and the formation energies of the stable Li-Si-O phases

\begin{tabular}{|c|c|c|c|c|c|}
\hline \multirow{2}{*}{ Material } & \multirow{2}{*}{ KPOINTS } & \multirow{2}{*}{$\begin{array}{l}\text { Total energy } \\
\text { (eV/formula) }\end{array}$} & \multicolumn{2}{|c|}{$\begin{array}{l}\text { Mole ratio } \\
\text { of reactants }{ }^{\mathrm{a}} \text { ) }\end{array}$} & \multirow{2}{*}{$\begin{array}{c}\begin{array}{c}\text { Formation } \\
\text { energy }\end{array} \\
\begin{array}{c}(\mathrm{eV} / \mathrm{unit} \\
\text { reactant })^{\mathrm{b})}\end{array}\end{array}$} \\
\hline & & & $\begin{array}{c}x \\
\left(\mathrm{Li}_{2} \mathrm{O}\right.\end{array}$ & $\begin{array}{c}\mathrm{y} \\
\left.\mathrm{SiO}_{2}\right)\end{array}$ & \\
\hline $\mathrm{Li}_{2} \mathrm{O}$ & $10,10,10$ & -14.327 & 1 & 0 & 0.00 \\
\hline $\mathrm{Li}_{2} \mathrm{Si}_{2} \mathrm{O}_{5}$ & $6,4,6$ & -63.207 & 1 & 2 & -0.49 \\
\hline $\mathrm{Li}_{2} \mathrm{SiO}_{3}$ & $6,10,6$ & -39.404 & 1 & 1 & -0.68 \\
\hline $\mathrm{Li}_{4} \mathrm{SiO}_{4}$ & $4,6,2$ & -54.294 & 2 & 1 & -0.64 \\
\hline $\mathrm{Li}_{6} \mathrm{Si}_{2} \mathrm{O}_{7}$ & $4,4,6$ & -93.506 & 3 & 2 & -0.62 \\
\hline $\mathrm{Li}_{8} \mathrm{Si}_{1} \mathrm{O}_{6}$ & $6,6,4$ & -83.084 & 4 & 1 & -0.41 \\
\hline $\mathrm{SiO}_{2}-\alpha$ & $6,6,6$ & -23.711 & 0 & 1 & 0.00 \\
\hline
\end{tabular}

${ }^{a)} \mathrm{x}$ and $\mathrm{y}$ are described in Eq. (10)

b) based on unit reactant having unity of $(x+y)$ in Eq. (10)

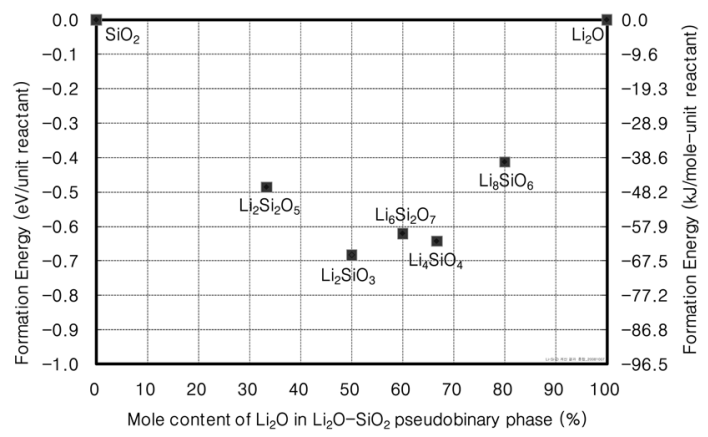

Fig. 5. The formation energies of stable Li-Si-O phases based on unit reactant.

phases are presentedbased on unit reactant and the corresponding values are listed in Table 2. Interpretations of the formation energies per unit product are difficult as the unit product has different content of $\mathrm{Li}_{2} \mathrm{O}$ and $\mathrm{SiO}_{2}$. The meaning of unit reactant was used as unity of $(x+y)$ in Eq. (10). $\mathrm{Li}_{2} \mathrm{SiO}_{3}$ has the lowest formation energy $\sim-0.68 \mathrm{eV}$ based on unit reactant of $\mathrm{Li}_{2} \mathrm{O}$ and $\mathrm{SiO}_{2}$ which is supposed to be the most stable phase material. Even though $\mathrm{Li}_{4} \mathrm{SiO}_{4}$ has some higher value of formation energy of $-0.64 \mathrm{eV}$, it remain as the only dominant product from the experiment rather than $\mathrm{Li}_{2} \mathrm{SiO}_{3}$, which shows that only $\mathrm{Li}_{4} \mathrm{SiO}_{4}$ is kinetically favored product. At higher temperature $1000^{\circ} \mathrm{C}^{36-37)}$ it is reported that $\mathrm{Li}_{4} \mathrm{SiO}_{4}$ is transformed into $\mathrm{Li}_{2} \mathrm{SiO}_{3}$.

Densities of Li-Si-O ternary materials are presented in Table 1, Fig. 6 showsdensities of the compounds along with corresponding densities of the compositional mixtures

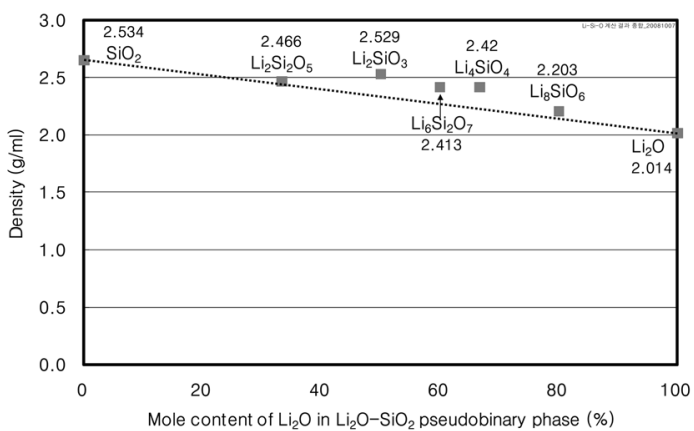

Fig. 6. Densities of Li-Si-O ternary materials.

of $\mathrm{Li}_{2} \mathrm{O}$ and $\mathrm{SiO}_{2}$. All ternary compositions have higher density than that of compositionally mixed materials. Density of $\mathrm{Li}_{4} \mathrm{SiO}_{4}(2.42 \mathrm{~g} / \mathrm{ml})$ is higher than that of $1 \mathrm{SiO}_{2}-2 \mathrm{Li}_{2} \mathrm{O}(2.226 \mathrm{~g} / \mathrm{ml})$ as a compositional mixture. Lithium insertion to silicon host accompanies volume expansion. This volume expansion is mitigated by buffer matrix. Buffering property of $\mathrm{Li}_{4} \mathrm{SiO}_{4}$ is considered to be better than that of material containing $1 \mathrm{SiO}_{2}-2 \mathrm{Li}_{2} \mathrm{O}$ from the consideration of densities. Therefore an improved cycle performance could be obtained from the improved buffer matrix.

Electronic conductivities of $\mathrm{Li}_{4} \mathrm{SiO}_{4}$ and $\mathrm{SiO}_{2}$ are $10^{-8} \sim 10^{-10} \mathrm{~S} / \mathrm{cm}$ at $100^{\circ} \mathrm{C}^{38)}$ and $10^{-14} \sim 10^{-18} \mathrm{~S} / \mathrm{cm}$ at room temperature, respectively. So, high conductivity of $\mathrm{Li}_{4} \mathrm{SiO}_{4}$ could contribute better to deliver high rate capability. Presence of $\mathrm{Li}_{4} \mathrm{SiO}_{4}$ acts as a buffer as wellas provides favorable lithium environment foreasy lithium ion diffusion and easy electron conduction.

\section{Conclusion}

Formation of $\mathrm{Li}-\mathrm{Si}-\mathrm{O}$ phases from $\mathrm{SiO}$ and $\mathrm{Li}_{2} \mathrm{O}$ has been discussed by first principle calculations through VASP. From the calculations it is expected that $\mathrm{Li}_{2} \mathrm{SiO}_{3}$ with its lowest formation energy $\sim-0.68 \mathrm{eV}$ has to be most stable phase. Contrary to this the experimental results showed the compound formed during slow heating of $\mathrm{Li}_{2} \mathrm{O}$ and $\mathrm{SiO}_{2}$ to reach $550^{\circ} \mathrm{C}$ is $\mathrm{Li}_{4} \mathrm{SiO}_{4}$ which has slightly higher formation energy of $-0.64 \mathrm{eV}$ than $\mathrm{Li}_{2} \mathrm{SiO}_{3}$. Synthesized material contained only $\mathrm{Li}_{4} \mathrm{SiO}_{4}$ and there is no evidence to the formation of $\mathrm{Li}_{2} \mathrm{SiO}_{3}$. This paradox could be explained by invokingthe kinetics which favors only the formation $\mathrm{Li}_{4} \mathrm{SiO}_{4}$ at those particular experimental conditions. The

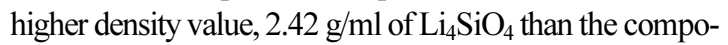
sitional mixture $1 \mathrm{SiO}_{2}-2 \mathrm{Li}_{2} \mathrm{O}(2.226 \mathrm{~g} / \mathrm{ml})$ and the ability to deliver sustainable long cycle life during charge- 
discharge as lithium anode material further confirms the stability of $\mathrm{Li}_{4} \mathrm{SiO}_{4}$ compound.

\section{Acknowledgement}

This work was supported by the Korea Research Council for Industrial Science \& Technology (ISTK), the Ministry of Knowledge Economy (MKE), and MEST \& DGIST(11-BD-0405) of Korea.

\section{References}

1. N. Dimov, K. Fukuda, T. Umeno, S. Kugino and M. Yoshio, J. Power Sources, 114,88 (2003).

2. N. Dimov, S. Kuginoand and M. Yoshio, Electrochim. Acta, 48, 1579 (2003).

3. C. H. Doh, H. M. Shin, D. H. Kim, Y. D. Jeong, S. I. Moon, B. S. Jin, H. S. Kim, K. W. Kim and D. H. Oh, A. Veluchamy, J. Alloys compd. 461, 321 (2008).

4. M. S. Park, S. Rajendran, Y. M. Kang, K. S. Han, Y. S. Han and J. Y. Lee, J. Power Sources, 158,650 (2006).

5. N. Jayaprakash, N. Kalaiselvi and C. H. Doh, Intermetallics, 15, 442 (2007).

6. N. Dimov, K. Fukuda, T. Umeno, S. Kugino and M. Yoshio, J. Power Sources, 114, 88 (2003).

7. C. H. Doh, H. M. Shin, D. H. Kim, Y. C. Ha, B. S. Jin, H. S. Kim, S. I. Moon and A. Veluchamy, Electrochem. Commun., 10, 233 (2008).

8. C. H. Doh, H. M. Shin, D. H. Kim, Y. C. Ha, B. S. Jin, H. S. Kim, S. I. Moon and A. Veluchamy, Electrochem. Commun., 10, 233 (2008).

9. M. Miyachi, H. Yamamoto, H. Kawai, T. Ohta and M. Shirakata, J. Electrochem. Soc.,152, A2089 (2005).

10. K. Schulmeister and W. Mader, J. Non-Cryr. Solids, 320, 143 (2003).

11. C. H. Doh, C. W. park, H. M. Shin, D. H. Kim, Y. D. Chung, S. I. Moon, B. S. Jin, H. S. Kim and A. Veluchamy, J. Powers Sources, 179, 367 (2008).

12. A. Veluchamy, C. H. Doh, D. H. Kim, J. H. Lee, D. J. Lee, K. H. Ha, H. M. Shin, B. S. Jin, H. S. Kim, S. I. Moon and C. W. Park, J. Power Sources, 188, 574 (2009).

13. Y. Lee and S. M. Lee, Electrochem. Commun., 6, 465 (2004).

14. J. H. Kim, H. J. Sohn, H. Kim, G. Jeong and W. Choi, J. Powers Sources, 170, 456 (2007).

15. C. H. Doh, H. M. Shin, D. H. Kim, Y. C. Ha, B. S. Jin, H. S. Kim, S. I. Moon and A. Veluchamy, Electrochem. Commun., 10, 233 (2008).

16. X. Yang, Z. Wen, X. Xu, B. Lin and S. Huang, J. Power
Sources, 164, 880 (2007).

17. T. Tabuchi, H. Yasuda and M. Yamachi, J. Power Sources, 146, 507 (2005).

18. A. F. Holleman and E. Wiberg, Inorg. Chem., San Diego: Academic Press, ISBN 0-12-352651-5, 2001.

19. C. A. Schacht, Refractories Handbook, CRC Press, ISBN $0824756541,2004$.

20. P. Jutziand U. Schubert, Silicon Chem.: from the atom to extended systems, Wiley-VCH ISBN 3527306471, 2003.

21. A. F. Hollemanand E. Wiberg, Inorg. Chem., San Diego: Academic Press, ISBN 0-12-352651-5, 2001.

22. C. H. Doh, H. M. Shin, D. H. Kim, Y. C. Ha, B. S. Jin, H. S. Kim, S. I. Moonand A. Veluchamy, Electrochem. Commun., 10, 233 (2008).

23. A. Veluchamy, C. H. Doh, D. H. Kim, J. H. Lee, D. J. Lee, K. H. Ha, H. M. Shin, B. S. Jin, H. S. Kim, S. I. Moonand C. W. Park, J. Power Sources, 188, 574 (2009).

24. G. Kresse and J. Hafner, Phys. Rev. B 47, 558(R) (1993); 49, 14251 (1994).

25. G. Kresse and D. Joubert, Phys. Rev., 59, 1758 (1999).

26. P. E. Blochl, Phys. Rev. B, 50, 17953 (1994).

27. J. P. Perdew, K. Burke and M. Ernzerhof, Phys. Rev. Lett. 77, 3865 (1996).

28. F. Zhou, C. A. Marianetti, M. Cococcioni, D. Morgan and G. Ceder, Phys. Rev., B, 69, 201101(R) (2004).

29. A. Veluchamy, C. H. Doh, D. H. Kim, J. H. Lee, D. J. Lee, K. H. Ha, H. M. Shin, B. S. Jin, H. S. Kim, S. I. Moonand C. W. Park, J. Power Sources, 188, 574 (2009).

30. A. Hohl, T. Wieder, P. A. van Aken, T. E. Weirich, G. Denninger, M. Vidal, S. Oswald, C. Deneke, J. Mayer and H. Fuess, J. Non-Cryst. Solids, 320, 255 (2003).

31. International Application published under the patent corporation treaty (PCT), International Publication Number WO 2004/093223 A2 dated 28.10.2004, PCT/US2004/ 011350.

32. X. Yang, Z. Wen, X. Xu, B. Linand S. Huang, J. Power Sources, 164, 880 (2007).

33. V. L. Chevrierand J. R. Dahn, J. Electrochem. Soc., 156, A454 (2009).

34. M. N. Obrovacand L. Christensen, Electrochem. Solid-State Letters, 7, A93 (2004).

35. A. Veluchamy, C. H. Doh, D. H. Kim, J. H. Lee, D. J. Lee, K. H. Ha, H. M. Shin, B. S. Jin, H. S. Kim, S. I. Moonand C. W. Park, J. Power Sources, 188, 574 (2009).

36. D. Cruz, S. Bulbulian, E. Limaand and H. Pfeiffer, J. Solid State Chemistry, 179, 909 (2006).

37. S. Claus, H. Kleykampand and W. Smykatz-Kloss, J. Nuclear Materials, 230, 8 (1996).

38. I. M. Hodge, M. D. Ingramand and A. R. West, J. Am. Ceram. Soc., 59, 360 (2006). 